\title{
MODEL PEMBELAJARAN CORE UNTUK MENINGKATKAN KEMAMPUAN PEMECAHAN MASALAH MATEMATIS BERBANTUAN MEDIA BATIK
}

\author{
Eni Luksiana $^{1}$ dan Jayanti Putri Purwaningrum ${ }^{2}$ \\ ${ }^{1}$ Prodi Pendidikan Guru Sekolah Dasar,Universitas Muria Kudus \\ ${ }^{2}$ Prodi Pendidikan Matematika, Universitas Muria Kudus
}

\begin{tabular}{|c|c|}
\hline Info Artikel & Abstract \\
\hline $\begin{array}{l}\text { Sejarah Artikel: } \\
\text { Diterima } 25 \text { Agt } 2018 \\
\text { Direvisi } 4 \text { Sept } 2018 \\
\text { Disetujui } 29 \text { Okt } 2018 \\
\text { Keywords: CORE model, } \\
\text { Batik Media, Problem } \\
\text { Solving Abilities }\end{array}$ & $\begin{array}{l}\text { This study aims to describe how the application of CORE (Connecting, Organizing, Reflecting, } \\
\text { Extending) model assisted by batik media can improve students' mathematical problem solving } \\
\text { abilities in mathematics subjects, and how much teacher teaching skill and student activity can be } \\
\text { improved through CORE (Connecting, Organizing, Reflecting, Extending) model with batik media. } \\
\text { The data collection technique used in this study consisted of tests and non-tests. The result of the } \\
\text { research showed that there was an increase of students' mathematical problem solving abilities in } \\
\text { cycle I (46,67\%) to cycle II (86,67\%), then improvement of teacher cycle teaching skill I (78,84\%) } \\
\text { increased to } 89,06 \% \text { in cycle II, and student activity also increase in cycle I }(69,47 \%) \text { to }(79,28 \%) \\
\text { cycle II. This study proves that the application of CORE (Connecting, Organizing, Reflecting, } \\
\text { Extending) model assisted by batik media can improve the abilites of mathematical problem solving, } \\
\text { teacher's teaching skill, and student activity. }\end{array}$ \\
\hline
\end{tabular}

Paper type:

Research paper

\begin{abstract}
Abstrak
Penelitian ini bertujuan mendeskripsikan seberapa besar penerapan model CORE (Connecting, Organizing, Reflecting, Extending) berbantuan media batik dapat meningkatkan kemampuan pemecahan masalah matematis siswa pada mata pelajaran matematika, serta seberapa besar keterampilan mengajar guru dan aktivitas siswa dapat meningkat melalui model CORE (Connecting, Organizing, Reflecting, Extending) berbantuan media batik. Teknik pengumpulam data yang digunakan dalam penelitian ini terdiri dari tes dan non tes. Hasil penelitian terdapat peningkatan yang meliputi kemampuan pemecahan masalah matematis siswa siklus I $(46,67 \%)$ meningkat menjadi $(86,67 \%)$ siklus II, kemudian terjadi peningkatan pada keterampilan mengajar guru siklus I $(78,84 \%)$ meningkat menjadi $(89,06 \%)$ siklus II, dan aktivitas siswa juga terjadi peningkatan pada siklus I $(69,47 \%)$ menjadi $(79,28 \%)$ siklus II. Hal ini membuktikan bahwa penerapan model pembelajaran CORE (Connecting, Organizing, Reflecting, Extending) berbantuan media batik dapat meningkatkan kemampuan pemecahan masalah matematis, keterampilan mengajar guru, dan aktivitas siswa.
\end{abstract}

(C) 2018 Universitas Muria Kudus

\footnotetext{
\Alamat korespondensi:

p-ISSN 2615-4196

Program Studi Pendidikan Matematika, Universitas Muria Kudus

e-ISSN 2615-4072

Kampus UMK Gondangmanis, Bae Kudus Gd. L. 1t I PO. BOX 53 Kudus

Tlp (0291) 438229 Fax. (0291) 437198

E-mail: jayanti.putri@umk.ac.id
} 
Eni Luksianan dan Jayanti Putri Purwaningrum

Anargya: JurnalPendidikanMatematika, Vol. 1 No.2, Oktober 2018

\section{PENDAHULUAN}

Pendidikan merupakan sarana penting untuk meningkatkan kualitas SDM untuk menjamin pengembangan pembangunan suatu bangsa. Di era global, pendidikan nasional banyak mengalami perubahan dalam pembelajaran menuju ke arah lebih baik. Faktor utama penyebabnya adalah perkembangan IPTEKS. Dengan demikian, perlu SDM berkualitas yang memiliki kemampuan untuk memproses informasi untuk dapat digunakan untuk dalam upaya pengembangan ilmu pengetahuan serta dapat menciptakan generasi yang sesuai dengan perkembangan zaman.

Berkaitan dengan pendidikan, matematika merupakan mata pelajaran yang wajib dipelajari siswa di sekolah, salah satunya di sekolah dasar. Berch \& Mazzzocca (Sari, 2017: 1) menjelaskan bahwa setiap siswa harus belajar matematika sebab matematika sangat berperan dalam kehidupan sehari-hari. Hal ini sama dengan pernyataan Astiningsih, dkk (2014: 3) yang menyatakan bahwa pada dasarnya matematika merupakan salah satu cabang ilmu yang sangat penting dalam kehidupan. Dengan demikian, kemampuan dan keterampilan siswa dalam menerapkan ilmu matematika harus dipelajari oleh siswa. Susanto (2013: 196) menyebutkan bahwa pemecahan masalah merupakan aktivitas yang sangat penting dalam pembelajaran matematika, karena tujuan belajar yang ingin dicapai dalam pemecahan masalah berkaitan dengan kehidupan sehari-hari.

$$
\text { Djamarah (Susanto, 2013: 197) }
$$

berpedapat bahwa kemampuan pemecahan masalah adalah suatu metode berpikir, sebab dapat di dalamnya digunakan berbagai metode yang dimulai dengan pencarian data sampai dengan penarikan kesimpulan. Dengan demikian, dapat dijelaskan bahwa pemecahan masalah merupakan suatu komponen yang sangat penting dalam matematika, karena dapat menerapkan pengetahuan yang telah diperoleh siswa sebelumnya ke dalam situasi baru.

Hasil observasi dan wawancara di SD 2 Pasuruhan Lor Kudus menunjukkan bahwa pelajaran matematika kurang diminati oleh siswa. Mereka beranggapan matematika merupakan mata pelajaran yang kurang menyenangkan dikarenakan sulit dalam menghafal rumus. Padahal, jika dilihat materi matematika adalah materi yang menantang dan menarik karena mengandung unsur-unsur bilangan, hitungan, waktu, serta perbandingan yang berhubungan dengan kehidupan sehari-hari. Selain itu, guru dalam pembelajaran masih menggunakan metode ceramah yang menurut siswa terkesan sangat membosankan dan pelajaran matematika menjadi menarik. Hal senada juga diungkapkan oleh Purwaningrum (2016: 137) yang menyatakan bahwa banyak orang menganggap matematika adalah ilmu yang sulit. Mereka menganggap matematika sebagai suatu kegiatan yang dilakukan dalam menjumlah, mengurang, mengalikan, dan membagikan. Tak jarang pula dari mereka juga menganggap matematika sebagai kegiatan yang berhubungan dengan menyelesaikan masalah hitungan dalam bentuk soal. Walaupun demikian, semua orang harus belajar matematika karena matematika merupakan salah satu alat untuk menyelesaikan masalah.

Penggunaan model pembelajaran yang kurang inovatif dalam pembelajaran matematika dirasa kurang efektif karena guru selalu mendominasi pembelajaran. Guru biasanya secara aktif menjelaskan, memberi contoh, dan latihan soal. Sedangkan siswa hanya duduk dan diam serta mencatat dan mengerjakan latihan yang diberikan oleh guru. Hal ini menjadikan siswa pasif, tidak memiliki kesempatan untuk menggali informasi, tidak memiliki kesempatan untuk bertanya mengenai hal-hal yang dirasa kurang paham, dan tidak memiliki kesempatan untuk mengungkapkan pendapat. Selama kegiatan belajar berlangsung, guru hanya menjelaskan di depan kelas dan guru juga tidak pernah berjalan untuk memantau siswa yang berada di belakang. Hal ini mengakibatkan banyak siswa yang berbicara sendiri dengan temannya, serta banyak siswa pula yang berusaha untuk mengganggu konsentrasi temannya dalam pembelajaran. Hal tersebut mencerminkan aktivitas siswa dalam pembelajaran menjadi tidak baik yang berdampak pada hasil kemampuan pemecahan masalah matematis siswa. Salah satu dampaknya adalah rendahnya nilai KKM pada mata pelajaran matematika. Siswa yang memperoleh nilai di atas KKM hanya berjumlah $23,3 \%$ dan sisanya ada $76,7 \%$ jumlah siswa yang masih memperoleh nilai di bawah KKM. Dilihat dari data tersebut dapat disimpulkan bahwa pengembangan kemampuan pemecahan masalah matematis kurang optimal.

Berdasarkan permasalahan di atas, diperlukan sebuah tindakan untuk menyelesaikan masalah pembelajaran matematika yang terdapat di kelas IV SD 2 Pasuruhan Lor Kudus. Salah satu solusinya adalah dengan menerapkan model pembelajaran yang inovatif yang melibatkan siswa dalam proses pembelajaran untuk membangun pengetahuannya. Hal ini dikarenakan model pembelajaran merupakan 
salah satu cara digunakan oleh guru untuk berinteraksi dengan siswa untuk membangun pengetahuannya dalam proses belajar mengajar. Model pembelajaran tersebut diantaranya adalah model pembelajaran CORE (Connecting, Organizing, Reflecting, Extending). Penerapan model ini dikarenakan dengan model pembelajaran tersebut guru sedikit menjelaskan materi pembelajaran, dan mengembangkan keaktifan siswa serta melatih daya ingat siswa tentang suatu konsep dalam materi pembelajaran. Dikarenakan dalam pembelajaran siswa diminta untuk membangun serta meningkatkan pengetahuannya untuk memperoleh suatu informasi, siswa juga melakukan aktivitas dengan menggali informasi-informasi yang didapat untuk dikembangkan menjadi lebih luas lagi bersama kelompoknya, dan siswa banyak berperan aktif sehingga pembelajaran menjadi bermakna. Hal ini seperti yang diungkapkan oleh Shoimin (2014: 39) yang menjelaskan bahwa langkah-langkah model pembelajaran CORE yaitu penyampaian konseplama yang akan dihubungkan dengan konsep baru oleh guru kepada siswa (Connecting), pengoranisasian ideide untuk memahami materi yang dilakukan oleh siswa dengan bimbingan guru (Organizing), pembagian kelompok secara heterogen, memikirkan kembali, mendalami, dan menggali informasi yang sudah didapat dan dilaksanakan dalam kegiatan belajar kelompok siswa (Reflecting), pengembangan, memperluas, menggunakan, dan menemukan, melalui tugas individu dengan mengerjakan tugas (Extending). Dengan hal ini, materi yang diteliti yakni mampu menganalisis sifat-sifat segibanyak beraturan dan segibanyak tidak beraturan. Dengan mempelajari materi tersebut siswa akan terbuka pola berpikirnya sehingga mampu memahami nilainilai yang terkandung dalam materi untuk diimplementasikan ke dalam kehidupan seharihari dengan lingkungan sekitarnya.

Berdasarkan penjelasan di atas, maka rumusan masalah dalam penelitian ini meliputi: (1) Bagaimanakah penerapan model CORE (Connecting, Organizing, Reflecting, Extending) berbantuan media batik dalam meningkatkan kemampuan pemecahan masalah matematis siswa pada materi menganalisis sifat-sifat segibanyak beraturan dan segibanyak tidak beraturan kelas IV SD 2 Pasuruan Lor? (2) Bagaimanakah keterampilan guru dalam pembelajaran matematika pada siswa kelas IV SD 2 Pasuruhan Lor melalui model CORE berbantuan media batik? (3) Bagaimanakah aktivitas siswa kelas IV SD 2 Pasuruhan Lor dalam pembelajaran matematika melalui model CORE berbantuan media batik.

\section{METODE PENELITIAN}

Jenis penelitian yang dilakukan dalam penelitian ini adalah penelitian tindakan kelas yang dilaksanakan pada siswa kelas IV SD 2 Pasuruhan Lor semester genap tahun ajaran 2017/2018. SD 2 Pasuruhan Lor ini teretak di Desa Pasuruhan Lor Kecamatan Jati Kabupaten Kudus. Penelitian dari observasi pra siklus hingga dilaksanakan tindakan.

Subjek dalam penelitian ini yaitu guru dan siswa kelas IV SD 2 Pasuruhan Lor Kudus. Subjek kelas IV berjumlah 30 siswa, terdiri dari 16 siswa laki-laki dan 14 siswa perempuan. Peneliti melakukan penelitian di kelas IV SD 2 Pasuruhan Lor Kudus karena adanya permasalahan pada rendahnya kemampuan pemecahan masalah matematis siswa kelas IV sehingga perlu untuk diadakan tindakan perbaikan.

Penelitian tindakan kelas dilaksanakan dalam 2 siklus menggunakan model yang dikemukakan oleh Kemmis \& Mc Taggart. Adapun gambar skemanya adalah sebagai berikut.

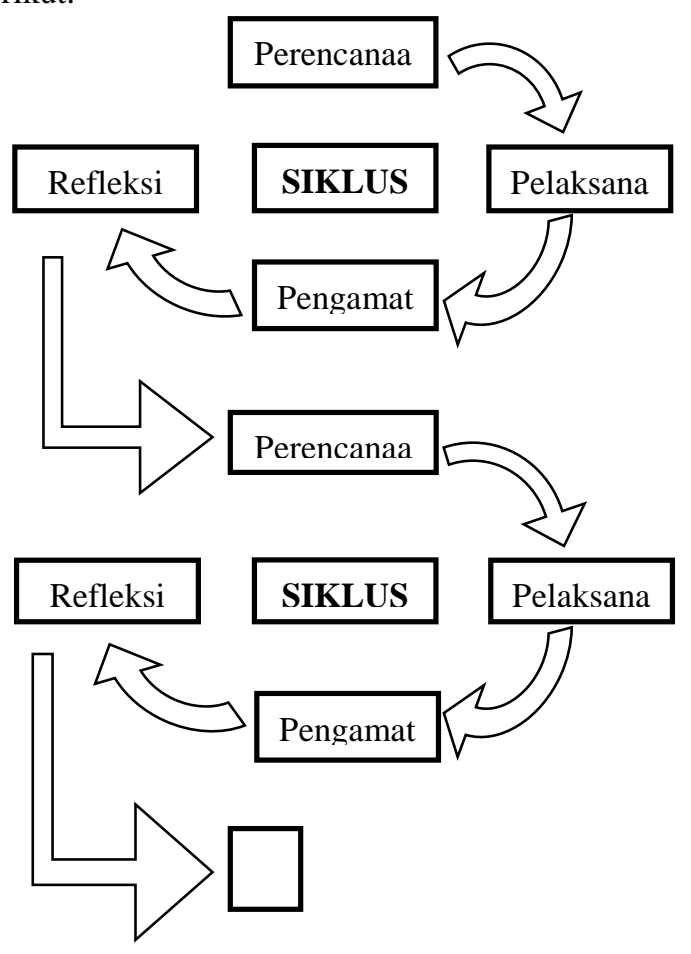

Gambar 1.Model PTK Desain Kemmis dan Mc Taggart

Teknik pengumpulan data yang digunakan dalam penelitian ini terdiri dari tes dan non tes. 
Instrumen tes digunakan untuk mengukur kemampuan pemecahan masalah matematis siswa aspek pengetahuan dalam bentuk tes uraian sebanyak lima soal sesuai indikator pemecahan masalah matematis. Adapun teknik non tes yang digunakan adalah wawancara, observasi dan dokumentasi.

Teknik analisis data yang digunakan dalam penelitian ini adalah analisis data kualitatif dan kuantitatif. Data kualitatif dianalisis menggunakan teknik analisis deskriptif sedangkan data kuantitatif disajikan dalam bentuk persentase dan angka.

\section{HASIL DAN PEMBAHASAN}

Hasil wawancara dan observasi yang dilakukan oleh peneliti menunjukkan bahwa terdapat masalah dalam pembelajaran yaitu kemampuan pemecahan masalah matematis siswa siswa masih tergolong rendah dan keterampilan mengajar guru dalam pembelajaran masih pada kriteria cukup. Hasil kemampuan pemecahan masalah matematis siswa pada pra siklus menmperoleh rata-rata sebesar 44,4 dengan ketuntasan klasikal sebesar 23,33\%. Sedangkan hasil observasi keterampilan mengajar guru pada pra siklus memperoleh skor 82 dengan rata-rata sebesar 2,56 persentase sebesar $64,06 \%$.

Hasil kemampuan pemecahan masalah matematis siswa pada siklus I diperoleh rata-rata sebesar 60,83 dengan persentase ketuntasan klasikal sebesar $46,67 \%$. Sedangkan pada siklus II diperoleh rata-rata sebesar 78,63 dengan persentase ketuntasan klasikal sebesar 86,67\%. Pada hasil observasi keterampilan mengajar guru pada siklus I memperoleh skor 202 dengan persentase rata-rata sebesar $78,84 \%$ atau kualifikasi baik. Sedangkan pada siklus II memperoleh skor 228 dengan persentase rata-rata sebesar $89,06 \%$ atau kualifikasi sangat baik. Hasil observasi aktivitas siswa pada siklus I diperoleh persentase rata-rata $69,48 \%$ dengan kualifikasi baik. Sedangkan pada siklus II diperoleh persentase rata-rata sebesar 79,28\% dengan kualifikasi baik.

Hasil kemampuan pemecahan masalah matematis siswa kelas IV SD 2 Pasuruhan Lor secara keseluruhan setelah diterapkannya model CORE dalam mata pelajaran matematika materi segibanyak beraturan dan segibanyak tidak beraturan mengalami 5 gejala yakni naik-naik tuntas terdiri dari 17 siswa dengan persentase sebesar $56,67 \%$. Kemudian untuk siswa yang mengalami gejala naik-naik tidak tuntas terdiri dari 4 siswa dengan persentase sebesar 13,33\%.
Pada gejala turun naik terdiri dari 7 siswa dengan persentase sebesar 23,33\%. Gejala tetap naik dialami oleh satu siswa dengan persentase $3,33 \%$. Sedangkan pada gejala naik tetap dialami oleh satu siswa dengan persentase $3,33 \%$.

Hasil pada siklus I memperoleh nilai maksimum 77 dan nilai minimum 24. Dengan siswa yang sudah tuntas sebanyak 14 siswa dan siswa yang belum tuntas sebanyak 16 siswa dengan diperoleh persentase klasikal sebesar 46,67\%. Sedangkan pada siklus II diperoleh nilai maksimum 100 dan nilai minimum 63. Dengan diperoleh siswa yang tuntas sebanyak 26 siswa dan siswa yang belum tuntas sebanyak 4 siswa dengan diperoleh persentase ketuntasan klasikal sebesar $86,67 \%$.

Hasil observasi keterampilan mengajar guru menggunakan model CORE pada pertemuan pertama memperoleh skor sebanyak 100 dengan persentase $78 \%$ atau kualifikasi baik. Sedangkan pada pertemuan kedua memperoleh skor sebanyak 102 dengan persentase 79,68\% atau kualifikasi baik. Kesimpulan yang dapat diambil berdasarkan data di atas adalah selalu terjadi peningkatan pada setiap pertemuan di siklus I. Berdasarkan hasil pada setiap pertemuan, diperoleh skor sebesar 202 dengan persentase rata-rata $78,84 \%$ atau kualifikasi baik. Sedangkan pada siklus II pada pertemuan pertama diperoleh skor sebanyak 110 dengan persentase $85,93 \%$ atau kualifikasi sangat baik dan pada pertemuan kedua memperoleh skor sebanyak 118 dengan persentase $92,18 \%$ atau kualifikasi sangat baik. Berdasarkan hasil observasi tersebut, diperoleh skor sebanyak 228 dengan persentase $89,09 \%$ atau kualifikasi sangat baik. Dari hasil observasi tersebut, dapat disimpulkan bahwa terjadi peningkatan observasi keterampilan mengajar guru pada siklus I ke siklus II.

Hasil observasi aktivitas siswa pada siklus I memperoleh skor sebanyak 520 dengan persentase $66,66 \%$. Pada pertemuan kedua diperoleh skor sebanyak 564 dengan persentase $72,30 \%$ atau kualifikasi baik. Berdasarkan hasil pengamatan pada setiap pertemuan, diperoleh skor sebanyak 1084 dengan diperoleh persentase sebesar $69,47 \%$ atau kualifikasi baik. Sedangkan pada siklus II pertemuan pertama diperoleh skor sebanyak 587 dengan persentase $75,25 \%$ atau kualifikasi baik dan pada pertemuan kedua diperoleh skor sebanyak 672 dengan persentase sebesar $83,32 \%$ atau kualifikasi sangat baik. Dari hasil observasi tersebut, dapat dikatakan bahwa terjadi peningkatan pada siklus I ke siklus II. 


\section{SIMPULAN}

Berdasarkan hasil penelitian tindakan kelas yang sudah dilaksanakan di dapat disimpulkan bahwa 1) Penerapan model pembelajaran CORE berbantuan media batik pada siswa kelas IV SD 2 Pasuruhan Lor Kudus dalam meningkatkan kemampuan pemecahan masalah matematis siswa pada pokok bahasan segibanyak beraturan dan segibanyak tidak beraturan dapat disimpulkan berhasil; 2) Penerapan model pembelajaran CORE berbantuan media batik pada siswa kelas IV dalam meningkatkan keterampilan mengajar guru berhasil sangat baik; 3) Penerapan model pembelajaran CORE berbantuan media batik pada siswa kelas IV SD 2 Pasuruhan Lor Kudus dalam meningkatkan aktivitas siswa berhasil dengan baik.

Implikasi dari hasil penelitian adalah bahwa dalam setiap pembelajaran matematika, sebaiknya guru lebih mengoptimalkan pembelajaran dengan menggunakan berbagai model pembelajaran yang inovatif untuk meningkatkan kemampuan matematis siswa.

\section{UCAPAN TERIMAKASIH}

Penulis mengucapkan terimakasih kepada segenap Tim Pengelola Jurnal Anargya UMK yang telah memberikan kesempatan kepada penulis untuk mempublikasikan karya ilmiahnya.

\section{DAFTAR PUSTAKA}

Arikunto, Suharsimi. 2011. Penelitian Tindakan Kelas Edisi 2. Jakarta: PT. Bumi Aksara

Astiningsih, Murda, dan Suarjana. 2014. Pengaruh Model CORE Berbantuan Media Manipulatif terhadap Hasil Belajar Matematika. Jurnal Mimbar PGSD Universitas Muria Kudus Pendidikan Ganesha, 2 (1).

Purwaningrum, J. P. 2016. Circuit Learning sebagai Upaya Mengatasi Kesulitan Belajar Matematika Siswa Sekolah Dasar. Prosiding Seminar Nasional Matematika dan Pendidikan Matematika (SENATIK) FPMIPATI Universitas PGRI Semarang. Dapat diakses di http://eprints.umk.ac.id/7317/

Sari, Novita, dan Edy Surya. 2017. Efektivitas Penggunaan Teknik Scaffolding dalam Meningkatkan Hasil Belajar Matematika pada Siswa SMP Swasta Al-Washliyah Medan. Edumatica, 7 (1).

Shoimin, Aris. 2014. 68 Model Pembelajaran Inovatif dalam Kurikulum 2013. Yogyakarta: Ar-Ruzz Media.
Susanto, Ahmad. 2013. Teori Belajar dan Pembelajaran di Sekolah Dasar. Jakarta: Prenada Media Group 
